\title{
Effect of Autumn Planting Date and Stand Age on Severity of Stem Rust in Seed Crops of Perennial Ryegrass
}

\author{
W. F. Pfender, USDA-ARS National Forage Seed Production Research Center and Oregon State University Depart- \\ ment of Botany and Plant Pathology, 3450 S.W. Campus Way, Corvallis, OR 97331
}

\begin{abstract}
Pfender, W. F. 2004. Effect of autumn planting date and stand age on severity of stem rust in seed crops of perennial ryegrass. Plant Dis. 88:1017-1020.

Perennial ryegrass (Lolium perenne) grown for seed is planted in autumn for July harvest (firstyear seed crop), then kept in production for subsequent yearly harvests. Plots of first-year perennial ryegrass planted in early November had only $3 \%$ as much stem rust in June as plots planted in mid-September. In other plots where fungicides were used to prevent rust development, seed yield from the November-planted plots was reduced by $23 \%$ compared with September-planted plots. In the second-year seed crop, stem rust severity in June was intermediate between severities in early- and late-planted first-year plots. The association of reduced stem rust severity with late planting for first-year crops was observed for five of six perennial ryegrass cultivars tested. Degree of reduction in disease severity due to planting date was greatest for the cultivars that had the highest disease severity in early-planted stands. Delay of autumn planting date may provide a useful cultural control method for first-year stands of perennial ryegrass seed crops.
\end{abstract}

Additional keywords: Puccinia graminis subsp. graminicola

Seed crops of perennial ryegrass (Lolium perenne) require winter conditions for floral induction (4). In the Willamette Valley of Oregon, where most of the U.S. crop of ryegrass seed is produced, the typical cultural practice is to plant fields in the autumn (mid-September to mid-November). After harvesting these first-year plantings in early July, they are maintained in production for several additional years. Summer rainfall is rare, so there is little regrowth of the harvested stands until the first autumn precipitation, which occurs in September or October. Grass-seed fields, whether first-year or older stands, therefore are in active growth from late September to late June.

The most damaging disease on perennial ryegrass seed crops in North America is stem rust, caused by Puccinia graminis subsp. graminicola. As in stem rust diseases of small grains, the disease caused by this pathogen on perennial ryegrass affects leaves, stems, and inflorescence, and the signs are especially striking on stems (10), where pustules occur in long strips with ragged edges of torn host epidermis. There are currently no commercial

Corresponding author: W. F. Pfender

E-mail: pfenderw@onid.orst.edu

Accepted for publication 11 May 2004.

Publication no. D-2004-0712-05R

This article is in the public domain and not copyrightable. It may be freely reprinted with customary crediting of the source. The American Phytopathological Society, 2004. cultivars of perennial ryegrass grown for seed in the Pacific Northwest that have sufficient genetic host resistance to reliably produce a crop without the use of fungicides (personal observation). Fungicides may be applied as many as five times between April and July in fields where stem rust appears early in the spring and weather conditions are favorable for continued epidemic development. Severity of the stem rust epidemic differs from year to year, but the most severely diseased fields in any given year are usually first-year stands (personal observation). Cultural practices that limit epidemic severity could reduce the number of fungicide applications required to protect a crop.

Choice of planting date within the season is a cultural practice that can affect plant disease development. For certain diseases, early planting results in less disease development than late planting (15). For many diseases of fall-planted crops, however, early planting can increase exposure to autumn inoculum, and thus infection. For example, this effect has been observed for some diseases of winter wheat $(2,3,5)$. If infections occurring in the autumn persist or reproduce through the winter, they can determine the local population levels of the pathogen available in the spring to initiate the epidemic. Roelfs (12) described four different geographical zones in North America with respect to weather conditions for overwintering of wheat rust infections. In the zone with the warmest winters, uredinial infections that occur in autumn invariably persist through the winter, but in the coldest zones, spring infections must arise from inoculum that arrives from outside the zone each year. The grass seed production regions of the Pacific Northwest are in an intermediate zone for wheat rusts where relatively few uredinial infections on autumn-planted wheat persist into April in most years (12). In this situation, winter weather can have a strong influence on spring epidemics through its effect on overwinter survival of the pathogen in colonies resulting from infections that occur in the fall or winter. Spring epidemics of stripe rust of wheat are more severe after mild winters than after cold winters in Oregon and Washington $(1,13)$. It is reasonable to expect that earlier planting in the autumn will provide more opportunity for the establishment of rust infections that can persist through the winter $(12,13)$. However, there are few reports of experimental data to demonstrate this effect. Steiner (14) observed that springtime severity of brown rust, caused by Puccinia triticina, was less in late-planted than in earlyplanted winter wheat in Germany. Although late autumn planting might reduce disease in spring, there may be disadvantages to late planting. A late-planted crop may produce lower yields than an earlyplanted crop in the absence of disease (9). Also, if later planting results in later maturity, the crop may be exposed to a more prolonged rust epidemic during the summer before harvest (9).

The influence of fall planting date on spring and summer epidemics of stem rust in perennial ryegrass seed crops is not known. A study of ryegrasses (including perennial ryegrass) grown for forage in Australia showed that springtime levels of crown rust (Puccinia coronata) were affected very little by fall planting date, although late planting reduced crown rust severity slightly in some years (8). Yield of forage harvested in the spring and summer was sometimes greater in the late-planted stands, due to better stand establishment under cooler conditions (8). The purpose of the experiments reported here was to determine whether date of fall planting has an influence on severity of stem rust in the spring for first-year perennial ryegrass seed crops in the northwestern United States, and whether seed yield potential is affected by planting date. Rust severity and yield in the first-year stands were compared also with those in established (second-year) stands. 


\section{MATERIALS AND METHODS}

General procedures. Experiments were conducted at the Oregon State University Hyslop Experiment Farm ( $44^{\circ} 38^{\prime} \mathrm{N}, 123^{\circ}$ $\left.12^{\prime} \mathrm{W}\right)$ located near Corvallis, OR. Standard grass-seed cropping practices were used. Seed was planted in autumn at the rate of $11 \mathrm{~kg} / \mathrm{ha}$, approximately $1 \mathrm{~cm}$ deep, in rows $30 \mathrm{~cm}$ apart. Weed control between rows was obtained by applying a broadspectrum, preemergence herbicide immediately after planting, with seed rows covered by a band of carbon to protect the seed by adsorbing the herbicide (7). The carbon was a suspension (5\%) of carbon particles in water, amended with fertilizer (7-7-0-6) that supplies $39 \mathrm{~kg}$ of $\mathrm{N}$ and $\mathrm{P}$ (as $\mathrm{P}_{2} \mathrm{O}_{5}$ ), and $33 \mathrm{~kg}$ of $\mathrm{S}$, per ha. The suspension was applied by a spray nozzle mounted behind each press wheel of the planter, producing a band of carbon $2.5 \mathrm{~cm}$ wide over the top of the closed planting furrow. The herbicide (Direx 4L [N'-(3,4 dichlorophenyl)- $N, N$-dimethylurea], Griffin Corporation, Valdosta, GA) was applied to the field at $2.7 \mathrm{~kg}$ a.i./ha in 187 liters of water. Additional $\mathrm{N}$ fertilizer (granular urea) was applied in mid-March and midApril each year, at a rate of $67 \mathrm{~kg} \mathrm{~N} / \mathrm{ha}$ for each application. Second-year stands received $42 \mathrm{~kg} / \mathrm{ha}$ each of $\mathrm{N}, \mathrm{P}\left(\right.$ as $\left.\mathrm{P}_{2} \mathrm{O}_{5}\right)$, and $\mathrm{K}$ in October, i.e., approximately 1 year after planting.

Severity of stem rust was determined in June of each year. For each measurement, a square frame with a $15 \times 15 \mathrm{~cm}$ opening was tossed arbitrarily into a plot and pressed down against the grass. The number of erumpent pustules of stem rust visible on the plant tissue within the frame opening $\left(225 \mathrm{~cm}^{2}\right)$ was counted. For severities $>100$ pustules per $225 \mathrm{~cm}^{2}$, severity was estimated as percent rusted leaf area, then converted to number of pustules $(1 \%$ $=140$ pustules $/ 225 \mathrm{~cm}^{2}$ ). Estimation of percent diseased leaf area was standardized by reference to keys constructed for that purpose. The keys were color photographs of perennial ryegrass with $0.7,1.4,2.8,5.5$, or $15 \%$ stem rust. Disease severity illustrated in each photograph had been estimated by means of digital image analysis.

Two experiments were conducted. One was designed to measure effects of stand age (first or second seed-crop year) and planting date (early or late autumn) within first-year stands on stem rust severity and yield potential in one cultivar of perennial ryegrass. In the second experiment, planting date (early or late) was assessed for its effect on stem rust severity in first-year stands of several different cultivars.

Stand age and planting date effects on yield potential and rust severity. Seed of perennial ryegrass cultivar Morningstar (Pennington Seed Company, Lebanon, OR) was planted in plots measuring $4.2 \times$ $6.0 \mathrm{~m}$. Plots were placed on a 0.85 -ha field such that there was a distance of $15 \mathrm{~m}$ of nonplanted ground between adjacent plots to allow access to plots for spraying and disease assessment without driving or walking in adjacent plots. The nonplanted areas were kept free of grasses and other weeds by means of herbicides. The planting date treatments were: early-planted first-year, late-planted first-year, and second-year stands. For each planting date treatment, there were two treatments with respect to management of stem rust: treated with fungicide (to compare planting dates for yield in the absence of rust), or nontreated (to compare planting dates for effect on rust development). The six treatments were arranged in the field as a completely randomized experimental design using four replications. The experiment was conducted in 1998 to 2000 and repeated in 1999 to 2001 .

In the experiment conducted for harvest in 2000, the planting dates for earlyplanted and late-planted first-year plots were 16 September 1999 and 3 November 1999. Second-year plots had been planted 20 September 1998. Rust severity was determined on 6 June 2000 by making five assessments of number of pustules per 225 $\mathrm{cm}^{2}$ in each plot and averaging them to produce the datum point for that replicate. Effect of planting date on yield potential (yield in the absence of disease) was determined by harvesting seed from the fungicide-treated plots. Stem rust severity was controlled to $<10$ pustules per $225 \mathrm{~cm}^{2}$ throughout the season in the fungicidetreated plots by applying $184 \mathrm{~g} / \mathrm{ha}$ propiconazole $(440 \mathrm{ml} / \mathrm{ha}$ Tilt $3.6 \mathrm{EC}$, Syngenta Inc., Basel, Switzerland) or $150 \mathrm{~g} / \mathrm{ha}$ azoxystrobilurin $(660 \mathrm{ml} / \mathrm{ha}$ Quadris $2.08 \mathrm{SC}$, Syngenta Inc.) as follows: Tilt on 19 April, 23 May, 5 June, and 19 June 2000; and Quadris on 12 May 2000. Fungicides were applied in 187 liters of water per hectare at a pressure of $129 \mathrm{kPa}$ (30 psi) with a mechanized sprayer. For application of Quadris, a surfactant $(2.8 \mathrm{~kg}$ a.i./ha of polyol fatty acid and derivatives; Agridex, Helena, MT) was added to the water. Plots for each planting-date treatment were swathed when the moisture content of the ripening seed had fallen to $35 \%$ (6). In 2000, early-planted first-year plots were swathed on 5 July, second-year plots on 6 July, and late-planted first-year plots on 7 July. After swathing, the cut plants were put into burlap bags where they were allowed to dry outdoors for 12 days, then dried overnight in a forced-air drier. Seed was threshed in a belt thresher, then cleaned of inert material to achieve industry standards for clean seed. Seed was airdried to a moisture content of $10 \%$, and weight of the cleaned seed from each plot was determined.

In the experiment conducted for harvest in 2001, planting dates were 16 September 1999 for the second-year treatment and 21 September and 6 November 2000 for early- and late-planted first-year treatments. Stem rust severity was determined on 19 June 2001 based on 10 measurements per replicate plot. Tilt and Quadris fungicides, used as previously described, were applied to fungicide-treated plots as follows: Tilt on 10 May and 3 June, and Quadris on 20 June. Fungicide-protected second-year plots were swathed on 2 July 2001. Early- and mid-planted first-year plots of protected ryegrass were swathed on 3 July, and late-planted first-year plots on 6 July. Seed was threshed and cleaned as previously described.

Comparison of cultivars. The effects of autumn planting date on spring stem rust severity in first-year stands of several different cultivars were compared in an experiment conducted in 2000 to 2001 and repeated (new plantings) in 2001 to 2002 . Six cultivars were chosen for the study. Although there are no published reports on severity of stem rust in these cultivars, our observations from preliminary trials indicated that they represent a range of stem rust reactions. Cultivars Jet, Morningstar, and Manhattan 4 are turf types commonly grown in the region, and they had previously shown a range of stem rust reactions from severely to moderately diseased, respectively. Forage cultivars Kingston and Marathon are early-heading, tall cultivars that are grown in New Zealand but not currently in the United States. In our preliminary trials, these cultivars had shown less severe rust than U.S. cultivars. Elka is a turf-type cultivar originating from material collected in the Netherlands, is extremely late-heading, and is occasionally grown in the United States. It developed moderately severe stem rust in our preliminary trials, but not until late in the season shortly after it flowered. Each year, the experiment was established as a completely randomized design with six replications for each of the six cultivars. Each replicate plot was $3 \mathrm{~m}$ long and 3 rows wide, with $1 \mathrm{~m}$ of bare ground between adjacent plots. Preliminary experiments in prior years had indicated that $1 \mathrm{~m}$ of separation between these small plots was sufficient to avoid interplot interference for observations taken early in the epidemic, before sufficient inoculum was present to be dispersed from one plot to another. The first time the experiment was conducted, early and late plantings were done on 5 October and 7 November 2000, respectively. Emergence dates were 20 October and 29 December 2000. Stem rust severity in these plantings was assessed on 6 June 2001 based on three measurements per replicate plot. When the experiment was repeated, early and late plantings were done on 4 October (emergence 16 October) and 6 November (emergence 27 December) 2001, respectively. Stem rust severity was determined on 3 June 2002.

Data analysis. Stem rust severity data were generally inappropriate for use in analysis of variance (ANOVA) due to inequality of variances among treatments. 

ing their logarithms, variances were equivalent and ANOVA was done. Data for seed yield required no transformation before analysis.

In the experiments comparing planting dates in first- and second-year plots, a oneway ANOVA to test the effect of planting date on spring stem rust severity was performed for each experiment (harvest years 2000 and 2001, respectively) separately. In addition, a two-way ANOVA was conducted with experiment year and planting date as the two factors. Data for seed yield from fungicide-protected plots in these experiments were analyzed similarly.

In the experiments comparing early and late planting dates for first-year stands of six cultivars, a three-way ANOVA was performed with experiment year, planting date, and cultivar as the factors. Because the analysis indicated significant interaction terms, an analysis to compare planting dates for each cultivar within each year was conducted.
After transforming the data values by tak-

\section{RESULTS}

Stand age and planting date effects on rust severity and yield potential. Severity of stem rust in perennial ryegrass cultivar Morningstar on 6 June 2000 was significantly greater in plots planted on $16 \mathrm{Sep}-$ tember 1999 than in those planted on 3 November 1999 (Table 1). Disease severity in plots that had been planted a year earlier (20 September 1998) was not significantly less than in the early-planted first-year plots $(P>0.05)$. When the experiment was repeated for the 2001 harvest year, the results were similar. The late-planted firstyear plots had significantly less stem rust than the early-planted first-year plots. Again, the estimated mean stem rust severity for the second-year plantings was not significantly different from severity in the early-planted first-year plots. With the improved statistical power of a two-way analysis of variance for the combined data from both years, the difference in rust severity between second-year and earlyplanted first-year perennial ryegrass was

Table 1. Effect of stand age and fall planting date on spring stem rust severity and yield potential of 'Morningstar' perennial ryegrass grown for seed

\begin{tabular}{lcccc}
\hline Harvest year & Stand age & Planting date & Rust severity $^{\mathbf{x}}$ & $\begin{array}{c}\text { Yield potential } \\
(\mathbf{k g} / \mathbf{h a})^{\mathbf{y}}\end{array}$ \\
\hline 2000 & 1st year & 16 Sep. 1999 & $536.0 \mathrm{a}$ & 1,850 \\
& 1st year & 3 Nov. 1999 & $9.5 \mathrm{~b}$ & 1,503 \\
& 2nd year & 20 Sep. 1998 & $124.9 \mathrm{a}$ & 1,576 \\
& & $P<0.001$ & $P=0.126$ (n.s.) \\
2001 & 1st year & 21 Sep. 2000 & $86.1 \mathrm{a}$ & $1,753 \mathrm{a}$ \\
& 1st year & 6 Nov. 2000 & $3.1 \mathrm{~b}$ & $1,254 \mathrm{~b}$ \\
& 2nd year & 16 Sep. 1999 & $26.5 \mathrm{a}$ & $1,996 \mathrm{a}$ \\
& & & $P=0.001$ & $P=0.008$ \\
Combined $^{\mathrm{z}}$ & 1st year & September & $217.8 \mathrm{a}$ & $1,801 \mathrm{a}$ \\
2000 and 2001 $^{201}$ & 1st year & November & $5.6 \mathrm{c}$ & $1,381 \mathrm{~b}$ \\
& 2nd year & September (prior year) & $57.9 \mathrm{~b}$ & $1,786 \mathrm{a}$ \\
& & & $P<0.001$ & $P=0.002$ \\
\hline
\end{tabular}

${ }^{\mathrm{x}}$ Number of stem rust pustules per $225 \mathrm{~cm}^{2}$ plant canopy in plots receiving no fungicide treatments. Severity measured on 6 June 2000 for harvest year 2000 and 19 June 2001 for harvest year 2001. Each value is the back-transformed average of $\log$ (pustules). Within each harvest year, values followed by the same letter do not differ at the 0.05 level, as determined by the Student-Newman-Keuls procedure. The $P$ value for treatment effects from the analysis of variance is shown for each data set.

y Seed yield from other plots of the same planting date, but with stem rust development prevented by fungicide applications. Plots harvested 5 to 7 July 2000 (2000 harvest year) and 2 to 6 July 2001 (2001 harvest year). Within each column and harvest year, values followed by the same letter do not differ at the 0.05 level, as determined by the Student-Newman-Keuls procedure. The $P$ value for treatment effects from the analysis of variance is shown for each data set. n.s. = no significant difference due to treatment.

${ }^{\mathrm{z}}$ Effect of planting date from two-way analysis of variance using harvest year and planting date as factors. statistically significant, and rust severity in late-planted first-year plots was significantly less than that in both other treatments. Seed yield potential of first-year perennial ryegrass was affected by fall planting date (Table 1). In stands kept free of stem rust by fungicide applications, seed yield was significantly less in November-planted plots than in Septemberplanted plots, as indicated in the two-way ANOVA of combined data from the 2 years. The reduction was not statistically significant in the separate analysis of the experiment harvested in 2000. Analysis of the combined data for 2 years showed no significant difference in yield between second-year and early-planted first-year plots.

Comparison of cultivars. The threeway ANOVA in this experiment showed a significant $(P<0.05)$ effect for experiment year, planting date, and cultivar. There was no significant interaction for experiment year by planting date (planting date significant in both years), but the other interaction terms were statistically significant. Because of the significant interaction terms, the analysis for effect of planting date for each cultivar and year of the study is presented in Table 2. For five of the six cultivars, disease severity of the lateplanted treatment was significantly $(P \leq$ $0.05)$ less than that of early-planted treatments in the first year of the study. Four of these five cultivars showed a similar effect when the experiment was repeated. One cultivar (Elka) showed no significant effect, in either year of the study, of fall planting date on stem rust severity in early June. The amount of decrease in disease severity due to late planting varied among the cultivars. Generally, cultivars with the greatest disease severity (as measured in early-planted plots) had the greatest decrease in disease severity attributable to late planting. For cultivar Elka, which had the lowest level of rust, there was no significant difference in severity of stem rust in June due to fall planting date.

\section{DISCUSSION}

Date of autumn planting consistently and statistically significantly reduced spring severity of stem rust in first-year

Table 2. Stem rust disease severity in June for perennial ryegrass cultivars planted early or late the previous fall

\begin{tabular}{lccccccc}
\hline & & \multicolumn{5}{c}{ Perennial ryegrass cultivar } \\
\cline { 3 - 7 } Year & Planting date & Jet & Morningstar & Manhattan 4 & Kingston & Marathon & Elka \\
\hline $2000-2001$ & 5 Oct. 2000 & $316.2^{y}$ & 18.6 & 8.2 & 11.0 & 7.9 & 2.5 \\
& 4 Nov. 2000 & 2.2 & 1.7 & 2.1 & 3.2 & 1.5 & 2.3 \\
$2001-2002$ & $P$ value & 0.001 & 0.001 & 0.04 & 0.05 & 0.01 & 0.95 \\
& 4 Oct. 2001 & 195.0 & 302.0 & 72.4 & 43.7 & 15.8 & 3.9 \\
& 6 Nov. 2001 & 26.9 & 11.7 & 4.1 & 10.0 & 2.0 \\
& $P$ value $^{\mathrm{z}}$ & 0.003 & 0.001 & 0.001 & 0.02 & 0.14 & 0.44 \\
\hline
\end{tabular}

${ }^{y}$ Number of rust pustules per $225 \mathrm{~cm}^{2}$ of grass canopy in first-year stands of ryegrass. Each value is the back-transformed average of log (pustules) from six replicate plots. Severity determined on 6 June 2001 for the 2000 plantings and 3 June 2002 for the 2001 plantings.

${ }^{\mathrm{z}} P$ value for difference between early- and late-planted treatments for each year within each cultivar, from three-way analysis of variance with experiment (year) number, planting date, and cultivar as factors. 
stands of Morningstar, a rust-susceptible perennial ryegrass cultivar. Stands planted in early November had only 2 to $4 \%$ as many rust pustules in early June as did stands planted in the latter half of September. There was a productivity cost to late planting, however, as late-planted stands produced a seed yield $23 \%$ less than the early-planted stands in plots where rust was essentially eliminated by the use of fungicides. Additional research is required to determine the factors involved (and their predictability) in balancing yield potential against disease hazard in choice of planting date. An additional possible disadvantage of late planting, prolonged exposure to the late-summer rust epidemic due to late crop maturity (9), seems unlikely for stem rust of perennial ryegrass in the $\mathrm{Pa}$ cific Northwest. The difference in maturity dates of early- and late-planted first-year crops was only 2 to 3 days, despite a difference of 7 weeks in planting dates. It is unlikely that this small difference in maturity date would expose the stand to significantly greater disease development. Furthermore, it may be possible to select an intermediate autumn planting date that would result in even less delay of maturity, and that would still have disease management benefits. From these considerations, it appears that planting date selection provides a useful cultural control for reducing severity of stem rust in first-year perennial ryegrass seed crops. This result is different from that observed for crown rust on ryegrass forage crops in Australia (8). Factors responsible for this discrepancy could include differences in pathogen biology, different climatic conditions during fall and winter, and differences in crop management between forage and seed crops.

Results further suggest that autumn planting date affects spring stem rust severity for most cultivars of perennial ryegrass, including turf and forage types of intermediate and early maturity. The observed differences in disease severity in early June, near the beginning of warm weather and rapid rust increase, can be expected to have an important impact on the number of fungicide applications required to manage disease for the remainder of the growing season. The most highly susceptible U.S. cultivars showed the greatest benefits to late planting. The New Zealand cultivars proved to be less susceptible to stem rust than the U.S. cultivars in these field experiments conducted in the United States. Nonetheless, the New Zealand cultivars also showed a significant effect of planting date on spring stem rust severity in three of four cultivar by year combinations. Additional field trials are needed to determine whether these cultivars have sufficient resistance for fullseason disease control of stem rust in the
United States. Cultivar Elka showed no significant effect of fall planting date on rust severity in early June. This cultivar is extremely late in maturity, and observations in other years (W. F. Pfender, unpublished) indicate that it becomes as severely diseased before harvest as the other U.S. cultivars tested, but this severe disease occurs later in the season for Elka. It is possible that stem rust observations taken later in the season would have shown an effect of planting date on disease severity for this cultivar, although interplot interference (inoculum from neighboring plots) would make these late observations less reliable than the observations in early June, before disease levels have become very high.

The association of early fall planting with increased rust severity in spring is probably not a direct result of plant tissue age, because another study (10) demonstrated that older tissue (which might predominate on early plantings at any given infection date) is generally less susceptible to infection than younger tissue. An alternative explanation that seems likely, although it was not directly tested, is the longer duration of exposure of early-sown plants to inoculum and infection in the fall. Overwinter weather conditions could then influence survival of rust colonies (pustules), the source of inoculum for infection in the spring. For example, previous experiments (11) showed that temperatures below $-6^{\circ} \mathrm{C}$ reduce survival of individual rust colonies in ryegrass. However, a full explanation of overwinter survival of rust must include more than direct effects of weather on prolonged survival of pustules because of the limited duration of individual pustules. It is possible that the leaves infected in the fall do not persist through the winter, but become senescent as part of normal plant growth and die before spring, thereby eliminating their resident rust colonies. Therefore, it may be necessary for repeated cycles of infection from local inoculum in order for the rust population to survive through the winter. In this scenario, fall infections would provide the starting population, and a larger population would have a greater probability of surviving, through reproduction, than a smaller population. The interaction of overwinter conditions with plant growth, pustule longevity, and autumn rust population would be the primary factors influencing spring rust population levels. A detailed study is in progress to quantify and model the factors involved in overwinter survival of stem rust on ryegrass plants.

If prolonged availability of host tissue for infection in the fall is the primary explanation for the association of early planting with increased spring rust severity, it is interesting that the second-year stands are less severely diseased in the spring than are the early-planted first-year stands. Second-year plants present a greater leaf area, with overall longer duration, in the autumn than do early-planted new crops. The older plants may be less susceptible to infection, and/or their dynamics of plant growth and leaf senescence in winter may be different from that of first-year plants and less favorable to survival of the rust population. These questions are being addressed in ongoing research.

\section{ACKNOWLEDGMENTS}

I thank Sheila Seguin for excellent technical assistance.

\section{LITERATURE CITED}

1. Coakley, S. M., and Line, R. F. 1981. Quantitative relationships between climatic variables and stripe rust epidemics on winter wheat. Phytopathology 71:461-467.

2. Colbach, N., Lucas, P., Cavelier, N., and Cavelier, A. 1997. Influence of cropping system on sharp eyespot in winter wheat. Crop Prot. 16:415-422.

3. Frank, J. A., Cole, H., Jr., and Hatley, O. E. 1988. The effect of planting date on fall infections and epidemics of powdery mildew on winter wheat. Plant Dis. 72:661-664.

4. Heide, O. M. 1994. Control of flowering and reproduction in temperate grasses. New Phytol. 128:347-362.

5. Kelley, K. W. 2001. Planting date and foliar fungicide effects on yield components and grain traits of winter wheat. Agron. J. 93:380389.

6. Klein, L. M., and Harmond, J. E. 1971. Seed moisture, a harvest timing index for maximum yields. Trans. Am. Soc. Agric. Eng. 14:121126.

7. Lee, W. O. 1973. Clean grass seed crops established with activated carbon bands and herbicides. Weed Sci. 21:537-541.

8. Lowe, K. F., Bowdler, T. M., and Mulder, J. C. 1986. Effect of early sowing on establishment, growth pattern and rust infection of annual sowings of ryegrass (Lolium spp.) in subcoastal Southeast Queensland. Trop. Grassl. 20:112-120.

9. McLeod, J. G., Campbell, C. A., Dyck, F. B., and Vera, C. L. 1992. Optimum seeding date for winter wheat in southwestern Saskatchewan. Agron. J. 84:86-90.

10. Pfender, W. F. 2003. Role of phenology in host susceptibility and within-plant spread of stem rust during reproductive development of perennial ryegrass. Phytopathology 94:308316.

11. Pfender, W. F., and Vollmer, S. S. 1999. Freezing temperature effect on survival of Puccinia graminis subsp. graminicola in Festuca arundinacea and Lolium perenne. Plant Dis. 83:1058-1062.

12. Roelfs, A. P. 1989. Epidemiology of the cereal rusts in North America. Can. J. Plant Pathol. 11:86-90.

13. Shaner, G., and Powelson, R. L. 1971. Epidemiology of stripe rust of wheat, 1961-1968. Oreg. Agric. Exp. Stn. Tech. Bull. 117.

14. Steiner, H. E. 1934. A contribution to the question of cereal rust control by cultural methods. Z. Pflanzenkr. Pflanzenschutz 44:348-345.

15. Sulc, R. M., and Rhodes, L. H. 1997. Planting date, fungicide, and cultivar effects on Sclerotinia crown and stem rot severity in alfalfa. Plant Dis. 81:13-17. 